\section{PEER-REVIEWED ARTICLE}

Food Protection Trends, Vol 41, No. 1, p. 70-79 Copyright 2021 , International Association for Food Protection 2900 100th Street, Suite 309, Des Moines, IA 50322-3855

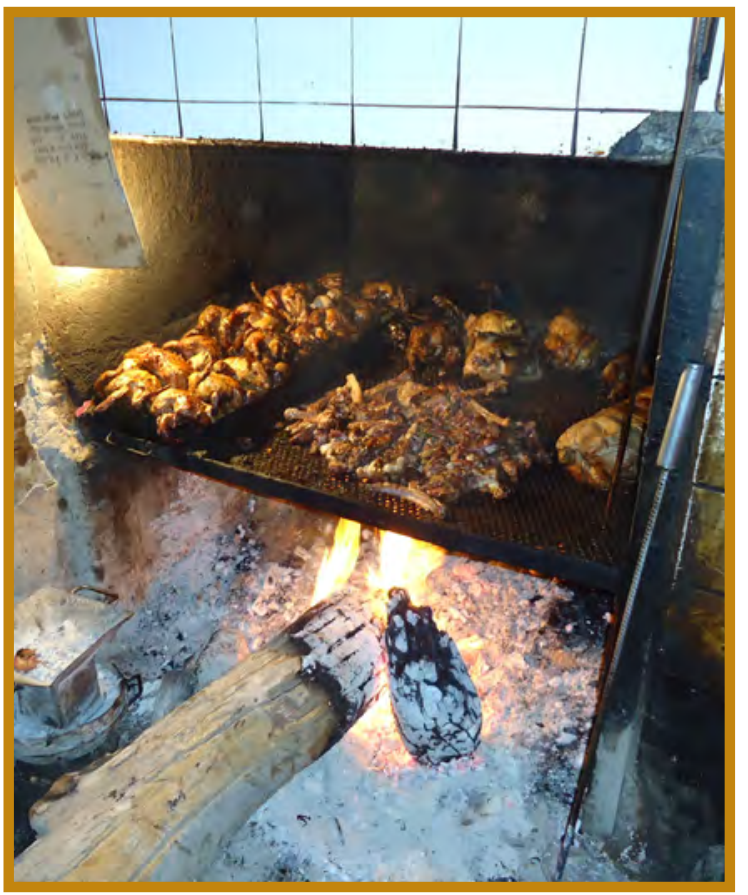

Sylvain Gnamien Traoré, ${ }^{1,2}$ Andrée Prisca Ndjoug Ndour, ${ }^{3}$ Walter Ossebi, ${ }^{3}$ Malik Orou Seko, ${ }^{3 *}$ Gilbert Fokou, ${ }^{2,4}$ Silvia Alonso, ${ }^{5}$ Philippe Soumahoro Koné, ${ }^{6}$ Kristina Roesel,, 7 Delia Grace, ${ }^{5}$ and Bassirou Bonfoh $2,8,9$

'Université Peleforo Gon Coulibaly, BP 1328 Korhogo, Côte d'lvoire ¿Centre Suisse de Recherches Scientifiques en Côte d'Ivoire, 01 BP 1303 Abidjan 01, Abidjan, Côte d'Ivoire

${ }^{3}$ Ecole Inter-Etats des Sciences et Médecines Vétérinaires, BP 5077 Dakar, Sénégal ${ }^{4}$ Human Sciences Research Council, 116-118 Buitengracht Street, Cape Town 8001 , South Africa

International Livestock and Research Institute, P.O. Box 30709, Nairobi 00100, Kenya Emergency Centre for Transboundary Animal Diseases, Food and Agriculture Organization of the United Nations, 936 Building 30 Juin, Kinshasa, Democratic Republic of the Congo Institute of Parasitology \& Tropical Veterinary Medicine, Freie Universtät Berlin, Robertvon-Ostertag-Strasse 7-13, 14163 Berlin, Germany

Swiss Tropical and Public Health Institute, P.O. Box CH-4OO2, Basel, Switzerland IUniversity of Basel, P.O. Box CH-40O3, Basel, Switzerland

\title{
Impact of Good Hygiene Management Practices on the Reduction in Microbial Contamination of Roasted Sheep Meat Sold at Urban Dibiteries in Senegal
}

\section{ABSTRAGT}

A cross-sectional study was conducted in Senegal in May 2015 on the microbial quality of roasted sheep meat in $\mathbf{4 0}$ selected dibiteries, which are informal and small fast-food restaurants offering roasted sheep meat to Senegalese consumers. An intervention was designed and implemented in these 40 dibiteries and coupled with an appraisal of the economic managerial performance of those restaurants to improve their hygiene management practices. The microbiological quality of roasted mutton was assessed 1 month before the intervention and then 2 and 10 months post-intervention. Three types of dibiteries were identified among the 40 units studied based on their production process: Senegalese [42.5\%], Mauritanian [40\%], and Nigerien [17.5\%). Of all samples analyzed, $70 \%$ were considered satisfactory regarding the levels of contamination at baseline; satisfactory scores rose to $75 \%$ at 2 months post-intervention and $83 \%$ at 10 months post-intervention. However, those differences were not statistically significant. The financial appraisal revealed that the performance of dibiteries before and after

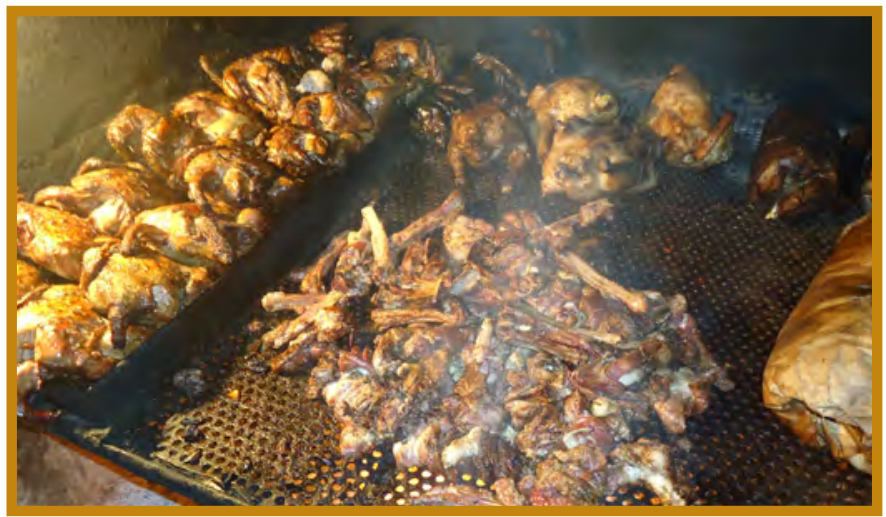

the intervention remained the same with no significant difference in the gross margins. Further studies are needed to understand compliance behavior and incentives that enhance the sustainability of hygiene management practices in the informal retail food sector.

\section{INTRODUCTION}

Animal-sourced foods are essential to the nutrition and livelihoods of low-income populations in sub-Saharan Africa. Although animal proteins represent a substantial dietary component for the human population, the livestock sector plays an important role in generating household incomes. In 2016, the global number of livestock was almost 30 million, accounting for $40 \%$ of global income from agriculture (7). Over the next three decades, both the price of animal products and their demand is predicted to continue to rise. If left unchecked, this rise will also increase the problems associated with the production and supply cycle of animal-sourced products, issues such as pressure on natural resources, increases in greenhouse gas emissions, and spread of infectious diseases (15). Among the infectious diseases, foodborne 
diseases are now a major public health concern, especially in low- and middle-income countries. According to the World Health Organization (18), foodborne diseases are most prevalent in Africa, where $>91$ million people become ill and 137,000 deaths are recorded each year, representing onethird of the global mortality. Diarrheal diseases account for $70 \%$ of the burden of foodborne diseases. Several risk factors play a decisive role in the occurrence of diarrheal diseases, including demographic factors, a low socio-economic status, lack of availability of drinkable water, poor water conservation methods, and the consumption of street foods (5).

In 2018, the livestock sector in Senegal included approximately 3,627,000 cattle, 7,132,000 sheep, 6,050,000 goats, 81,000 poultry, and 451,000 pigs, and these animals contributed to income generation, food security, and major sociocultural events such as Tabaski, the Islamic feast of the ram (14). Safe handling of livestock products requires hygiene awareness and rigor in implementing standard hygiene procedures along the supply chain. Those requirements are often lacking in the informal food supply sector in low- and middle-income countries.

Most of the meat consumed in Dakar, the capital city of Senegal, is sold within the largely unregulated informal sector. The various members of this sector (e.g., butchers, meat carriers, and local restaurant vendors) are often unaware of basic hygiene practices required for food safety and can contribute to the growth and spread of pathogens in meat products during processing and sales. In a study on Salmonella contamination in raw beef at slaughterhouses and retail establishments in Dakar, 275 (63\%) of the 435 meat samples tested were positive for Salmonella (17). In another study conducted on broiler farms in Casamance, southwestern Senegal, Salmonella was found in $35.1 \%$ of fecal samples from farmed chickens, $38.6 \%$ of carcass skin samples, and $29.8 \%$ of muscle tissue samples (4). Yougbaré (20) investigated slaughterhouses and traditional kiosks selling roasted meat in Dakar, locally called dibiteries, and found that the contamination of raw meat had acceptable levels of fecal coliforms, Escherichia coli, and total aerobic mesophilic bacteria (TAMB) and satisfactory levels of anaerobic sulfitereducing bacteria and Staphylococcus aureus. However, roasted sheep meat (RSM) samples in half of the 40 dibiteries assessed were unsatisfactory for fecal coliforms, E. coli, and mesophilic bacteria. Dibiteries are popular restaurants specializing in preparing and selling roasted meat of small ruminants, mainly sheep (16). These informal businesses are most commonly managed by men from Senegal, Mauritania, or Niger. Dibiteries are usually located in buildings equipped with a chimney and with a separation between the eating space and the working space where the meat is prepared and roasted (16). High-risk practices in meat handling can be regularly observed in those restaurants, including displaying meat pieces in the open air, using recycled cement bags for packaging meat, and lack of gloves or hand washing by the vendor between handling of money and handling of meat products. Poor hygiene is one of the main causes of spoilage of animal products, resulting in a loss of income (3). However, few studies have been conducted to assess the hygiene conditions of the production and sale of animalsourced food in the informal retail sector in Senegal.

The main objective of this study was to improve the microbiological quality of RSM sold in dibiteries in Dakar by assessing the economic and managerial performance of these outlets, the quality of their roasted meat products, and the effectiveness of an intervention designed to improve hygiene practices.

\section{MATERIALS AND METHODS}

\section{Study design and intervention}

A cross-sectional study to evaluate the microbial quality of RSM was conducted in May 2015 in the same 40 dibiteries that were previously targeted in a study by Yougbaré (20). After this baseline assessment, an intervention targeting hygiene behavior was designed and implemented in the dibiteries to improve sheep meat quality and hygiene conditions. The intervention was conducted from June 2015 to April 2016 and was coupled with an appraisal of the economic and managerial performance of those restaurants.

The intervention consisted of a training of selected owners or tenants of dibiteries and distribution of basic hygiene kits and products. The effects of the intervention were assessed in a randomized, single-blind controlled trial in which dibiteries were randomly allocated to an intervention or control group. Four groups of 10 dibiteries were defined as follows: group 1 received no intervention; group 2 received a training package on good hygiene practices (i.e., eating space, body hygiene, clothing, equipment, and materials) and hygienic packaging of RSM; group 3 received basic hygiene kits and products; and group 4 received training, basic hygiene kits, and products. The hygiene kits consisted of a minimum package of items that any dibiterie should have on hand to comply with good hygiene practices: a bucket, scrubbing brush, coat, cap, apron, trashcan, and floor cloth. The products provided included chorine-based bleach, paper towels, and liquid soap. The microbiological quality of RSM from the dibiteries was assessed at baseline (1 month before the intervention) and then at 2 and 10 months after the intervention. The major inclusion criterion for selection of dibiteries in this study was access to a source of clean water, especially for drinking and cleaning purposes, from the Senegalese Water Company.

The training workshop therefore involved groups 2 and 4 (20 total dibiteries, 10 per group) without any particular criteria of customizing applied to the set. During this training workshop, which was translated into the local language (Wolof), the importance of hand washing, cleaning of premises, disinfection of equipment, and personal and clothing hygiene were presented and discussed with the dibiterie tenants. Key messages were elaborated on the risky 


\section{TABLE 1. Main messages promoted during the training of dibiterie tenants in Dakar}

\begin{tabular}{c|l}
\hline No. & Message \\
\hline 1 & Cut nails short and wash your hands and if necessary disinfect hands regularly. \\
\hline 2 & Use butcher paper, not cement paper, to pack the meat served to the customer. \\
\hline 3 & The person who takes the money should not be the one serving the meat. \\
\hline 4 & Avoid hanging the meat in the open air without any protection. \\
\hline 5 & Never reuse a utensil without having previously cleaned and disinfected it. \\
\hline 6 & Do not wet the fingers with saliva when handling the packaging paper. \\
\hline 7 & Keep city clothes and work clothes separate. \\
\hline 9 & Wear waterproof and nonslip boots or shoes. \\
\hline 10 & Remove all jewelry before starting work. \\
\hline 11 & Treat and protect skin infections and injuries. \\
\hline 12 & Wash and change work clothes regularly. \\
\hline 13 & $\begin{array}{l}\text { Do not cough, sneeze, blow your nose, wipe the sweat off with your hands, or scratch without washing your hands, and do } \\
\text { not talk too much during the handling of the meat. }\end{array}$ \\
\hline 14 & Keep trash cans away from the work area, keep them closed, and empty them often. \\
\hline 15 & Store cleaning materials and products in a separate location. \\
\hline 16 & Respect the work flow from the dirty sector to the clean sector to avoid cross-contamination. \\
\hline 17 & The floor must be washed and disinfected at the end of each working day. \\
\hline 18 & $\begin{array}{l}\text { The equipment must be washed, disinfected, and dried at the end of each working day and stored in a clean place away from } \\
\text { dust and pests (e.g., flies, cockroaches, and rats). }\end{array}$ \\
\hline
\end{tabular}

practices related to hygiene as identified by Yougbaré (20).

The 18 key messages provided are listed in Table 1.

Illustrations of handwashing and photographs taken at some dibiteries showing poor hygiene practices were presented to participants. Correct handwashing procedures were demonstrated, and participants were encouraged to use these procedures during practical exercises. Participants were also encouraged to clean (remove dirt and shine surfaces) and disinfect (remove pathogenic microbes) the premises (floors, walls, and toilets) and equipment (e.g., knives and utensils) according to three distinct methods or successive steps (Table 2): (i) prewashing with water to remove solid materials and fat; (ii) washing with water and soap to remove fat; (iii) rinsing with water; (iv) disinfection with diluted bleach and rinse with water; and (v) drying.

A disinfection procedure was also demonstrated by soaking the equipment in the diluted bleach solution $\left(\right.$ sodium hypochlorite, chlorometric assay $\left.=12^{\circ}\right) ; 100 \mathrm{~mL}$ of bleach was poured into a $10-\mathrm{L}$ basin of water, and the equipment was immersed in the solution for $15 \mathrm{~min}$, rinsed with drinking water to remove the disinfectant, and dried.

\section{Assessment of microbiological quality of RSM}

The original study design stipulated that a single sample of RSM was to be collected from each of the 40 dibiteries assessed at the baseline ( 1 month before intervention) and at 2 and 10 months after intervention. Although 40 samples were collected at baseline and 40 samples were collected 2 months post-intervention, only 35 samples were collected 10 months post-intervention; five samples were missing because five dibiteries included in the study had closed. Thus, 115 total samples were collected at the three collection times. A sample consisted of a whole portion of meat as offered to consumers in the dibiteries, i.e., cut into pieces with some added seasoning ingredients (e.g., onions, chilli, and grounded spices). Our aim was to collect samples of RSM that was ready to be consumed. No instruments were used in the dibiteries to check the cooked status of the meat. In general, the dibiterie tenants estimated the proper cooking time and temperature; according to them, well-cooked meat has no more blood. This guideline was used to determine the cooking level and to choose the samples of well-cooked RSM. However, only sheep meat, which is the main product of the dibiteries, was collected for this study. Samples were packed in recycled cement bags, stored on ice in a cooler, 


\begin{tabular}{l|l}
\multicolumn{2}{c}{ TABLE 2. Main cleaning and disinfection methods described during the training of the } \\
tenants of dfbiteries \\
\multirow{2}{*}{ Step } & Operation(s) \\
\hline \multirow{2}{*}{ Before cleaning } & Put away objects (throw away waste) \\
\cline { 2 - 2 } Cleaning & Prewash with cold or hot water $\left(40-50^{\circ} \mathrm{C}\right)$ to remove most of the soil \\
\hline \multirow{2}{*}{ Disinfection } & Remove soil with soap (detergent) and brushing (mechanical action) for $10-30$ min \\
\cline { 2 - 2 } & Rinse with water (intermediate rinse) to remove residues \\
\hline & Apply cold chlorine solution for 15 min to destroy bacteria \\
\cline { 2 - 2 } & Rinse (final rinse) with cold drinking water to remove all traces of the disinfectant \\
\cline { 2 - 2 } & Dry and put away \\
\hline
\end{tabular}

and transported to the Laboratory of Hygiene and Industry Foodstuffs of Animal Origin (HIDAOA) of the Interstate School of Veterinary Sciences and Medicine (EISMV) in Dakar. At the lab, the RSM and ingredients were ground, and $10 \mathrm{~g}$ of the mixture was processed according to the protocol defined by the Association Française de Normalisation and the International Organization for Standardization standards for research on total aerobic mesophilic flora (TAMF) (8), coliforms (9), and S. aureus (10).

For microbiological analysis in the laboratory, culture media used were plate count agar for TAMF at $30^{\circ} \mathrm{C}$, violet red bile lactose agar for coliforms, and Chapman mannitol agar for S. aureus. All culture media were sterilized in an autoclave at $121^{\circ} \mathrm{C}$ for $15 \mathrm{~min}$ then cooled in a water bath at $45 \pm 0.5^{\circ} \mathrm{C}$. Prepoured agar plates also were used. For each sample, $10 \mathrm{~g}$ of ground sample mixture was placed into 90 $\mathrm{mL}$ of peptone water and ground with Stomacher bag in a sterile manner. A series of dilutions were made $\left(10^{-1}\right.$ to $\left.10^{-9}\right)$, and $1 \mathrm{~mL}$ of the appropriate dilution was directly plated in triplicate on agar plates.

The samples were classified based on the bacterial enumeration results as satisfactory, acceptable, and not satisfactory according to the criteria of HIDAOA. These criteria allow determination of the quality or safety of foodstuffs according to French standards for TAMF and $S$. aureus (13) and the European Union standard for coliforms (6). The three categories were defined as follows: (i) satisfactory, below the standard or $<3$ times the standard; (ii) acceptable, 3 to 10 times the standard; (iii) not satisfactory, greater than the standard or $>10$ times the standard (1). Thus, to consider a sample satisfactory based on the levels of the three bacterial groups, all results had to be satisfactory. Samples were classified as not satisfactory when at least one of the results for that sample was not satisfactory. To be classified acceptable, at least one result had to be acceptable and the other two had to be satisfactory.
Descriptions and socioeconomic profiles of dibiteries

Descriptions and socioeconomic profiles were acquired during individual interviews with the tenants of dibiteries ( $n$ $=40$ ) to simulate the economic impact of the intervention. Data collected from the tenants of dibiteries included information on (i) demographics and socioeconomic status, (ii) infrastructure, (iii) level of education and training of personnel employed, (iv) cost of equipment (e.g., table, television, refrigerator, and garbage can), (v) purchased foodstuffs (input), (vi) products sold (output), (vii) cleaning and disinfection process, and (viii) transportation and taxes.

\section{Financial appraisal and economic performance}

The economic performance of dibiteries before and after the hygiene intervention was estimated by the enterprise profit and loss method (11) to assess the effect of quality improvement (investment) on profitability and included the calculation of gross margin and gross margin rate, net profit, operating result ratio, and rate of return.

The value of renewable and durable equipment was estimated in terms of cost per month. We assumed that dibiteries had made some investments in durable equipment such as tables, TV sets, refrigerators, and garbage bins, which can be amortized over 3 years. For the dibiterie tenants who were renting the business premises, the rental fees per month were considered a cost. On this basis, different intervention scenarios were compared to assess the effect on the economic profitability of the investments made in improvement of the hygiene of the dibiteries and the quality of the meat sold.

\section{Statistical analysis}

Data collected were double entered and recorded on Sphinx software version 5 (https://www.sphinx-doc.org/ en/stable/) and exported into SPSS Statistics software version 20 (SPSS, IBM, Armonk, NY) for descriptive and analytical analysis using univariate and bivariate tests (i.e., chi-square tests and one-way analyses). Additional one-way 
analyses were performed with the generalized linear models procedure for comparison of microbial loads with $\mathrm{R}$ version 3.5.0 software (https://www.r-project.org/). The chi-square test was used to identify potential relationships between the groups and the impact of any intervention on the reduction of the contamination of RSM. A pairwise comparison was performed applying the chi-square test according to the procedure defined by Marascuilo and Serlin (12) to the threshold $\alpha=5 \%$.

\section{Ethical clearance, informed consent and equity}

The study was conducted upon approval by the Ministry of Livestock of Senegal and the ILRI Institutional Research Ethics Committee (ILRI-IREC2014-07). Oral informed consent of the tenants of dibiteries was obtained prior to data collection. After the study, the same equipment and consumables given to dibiteries of groups 3 and 4 were distributed to dibiteries of group 1 (received no intervention) and group 2 (received training only).

\section{RESULTS}

\section{Meat processing}

Three types of dibiteries were identified based on their production processes. However, according to their own descriptions, tenants of dibiteries distinguished only two types of dibiterie meat: Hausa dibi and Senegalese or

Moorish dibi; dibi is the name given to the roasted meat from a dibiterie. The Hausa dibiteries owe their name to the origin of tenants of this type of restaurant who are mainly from the Hausa ethnic group in Niger and who introduced a certain roasting technique in Senegal a few decades ago. The second type of dibiteries was established by tenants of Senegalese and Mauritanian origin. In the Hausa dibiteries, after purchasing a living sheep the tenant brings it to the slaughterhouse where the animal is shot, skinned, eviscerated, and inspected. The unrefrigerated carcass is then transported to the dibiterie by bus, taxi, or motorcycle. At the dibiterie, the carcass (cut or whole) is immediately put onto a traditional charcoal oven. The well-cooked meat is placed on paper, often from used milk bags or similar bags, and served to consumers in small pieces with added salt, chopped raw onion, mustard, pepper, and kan-kan, a spiced blend made of groundnut, chili powder, pepper, culinary broth, salt, and garlic.

The Moorish and Senegalese dibiteries follow the same process as the Hausa dibiteries from buying a living sheep to its transportation to the dibiterie. However, at that point the carcass is then cut into pieces and placed into a refrigerator, if electricity is available. In some dibiteries, part of the carcass remains hanging from the ceiling for customers to observe the freshness of the product. The meat is then roasted over a wood fire after adding salt. Moorish dibiteries use the fat of the animal rather than oil and add onions while the meat is on the fire. The meat is cut into small pieces and served to the consumers with mustard and a mixture of pepper and broth.
In the Senegalese dibiteries, meat is cooked on a grill with fresh raw chili, broth, pepper, and oil.

\section{Socioeconomic profile of dibiteries}

According to the socio-demographic profile of tenants, the same three types of dibiteries were identified among the 40 dibiteries studied: (i) Hausa $(\mathrm{n}=7 ; 17.5 \%)$, (ii) Moorish ( $n=16 ; 40 \%)$, and (iii) Senegalese $(n=17 ; 42.5 \%)$. For all $(100 \%)$ tenants from the Hausa ethnic group, RSM was their only business, and the product was usually sold at 2.2 \pm 0.5 USD per portion. The tenants of the Moorish dibiteries are of Mauritanian origin. Most (93.75\%) were not formally educated, and sales of RSM was their main activity (100\%). RSM in Moorish dibiteries was sold at $7.8 \pm 0.5$ USD per kg or 1.6 \pm 0.5 USD per portion. In Senegalese dibiteries, the raw and cooked meat was sold at $7.7 \pm 0.5$ USD per kg or $1.8 \pm 0.6$ USD per portion according to the financial means of the consumer. The tenants of Senegalese dibiteries are of Senegalese or Guinean origin. The Senegalese dibiteries were mostly run by families, in contrast to Hausa and Moorish dibiteries, which were managed by tenants without their families. Selling RSM was the main activity of most Senegalese tenants (94.1\%); however, secondary activities such as trade or sale of sheep were additional sources of income for the owner (5.9\%). All (100\%) tenants of these three types of dibiteries were men who rented rather than owned the premises, and most of them were married and had more than 14 years of professional experience. The majority of the tenants received training from male relatives (e.g., uncle or father) in good hygiene practices, and they were able to cover their needs with the income derived from the RSM sales (Table 3).

\section{Microbiological quality of RSM}

The baseline study 1 month before the intervention revealed that based on international standards $70 \%$ of RSM samples were satisfactory regarding contamination with TAMB, coliforms, and S. aureus. Post-intervention assessments revealed that $75 \%$ of samples from the same dibiteries were satisfactory 2 months after the intervention and $83 \%$ were satisfactory after 10 months; however, the difference between pre- and post-intervention was not significant (Table 4).

One month before the intervention, the microbial load (TAMB, coliforms, and S. aureus) did not differ between the RSM samples from the three types of dibiteries (Table 5). However, 2 months after intervention, the RSM from the Hausa dibiteries had a higher average load than did the RSM from the Moorish and Senegalese dibiteries $(P<0.05)$. Ten months after the intervention, only the RSM from the Hausa dibiteries had a higher average load of the TAMB compared with the RSM from the Moorish dibiteries $(P<0.05)$. No significant difference in fecal coliforms and $S$. aureus was observed for the RSM from the three types of dibiteries. 


\section{TABLE 3. Socio-demographic profiles of the tenants of three types of dibiteries $(n=40)$}

\begin{tabular}{|c|c|c|c|}
\hline \multirow[t]{2}{*}{ Category } & \multicolumn{3}{|c|}{ No. $(\%)$} \\
\hline & Hausa $(n=7)$ & $\operatorname{Moorish}(n=16)$ & Senegalese $(n=17)$ \\
\hline \multicolumn{4}{|l|}{ Sex } \\
\hline Male & $7(100)$ & $16(100)$ & $17(100)$ \\
\hline Female & 0 & 0 & 0 \\
\hline \multicolumn{4}{|l|}{ Owner-manager } \\
\hline Yes & $4(57.1)$ & $13(81.3)$ & $15(88.2)$ \\
\hline No & $3(42.9)$ & $3(18.8)$ & $2(11.8)$ \\
\hline \multicolumn{4}{|l|}{ Formal education } \\
\hline Yes & $4(57.1)$ & $1(6.3)$ & $10(58.8)$ \\
\hline No & $3(42.9)$ & $15(93.8)$ & $7(41.2)$ \\
\hline \multicolumn{4}{|l|}{ Marital status } \\
\hline Single & 0 & $1(6.3)$ & $1(5.9)$ \\
\hline Married & $7(100)$ & $15(93.8)$ & $16(94.1)$ \\
\hline \multicolumn{4}{|l|}{ Nature of business } \\
\hline Individual & $5(71.4)$ & $2(12.5)$ & $1(5.9)$ \\
\hline Family & $2(28.6)$ & $14(87.5)$ & $16(94.1)$ \\
\hline Professional experience $(\mathrm{yr})$ & $14 \pm 8$ & $19 \pm 10$ & $20 \pm 10$ \\
\hline \multicolumn{4}{|l|}{ Main activity } \\
\hline Yes & $7(100)$ & $16(100)$ & $16(94.1)$ \\
\hline No & 0 & 0 & $1(5.9)$ \\
\hline \multicolumn{4}{|l|}{ Local property } \\
\hline Owner & 0 & 0 & 0 \\
\hline Tenant & $7(100)$ & $16(100)$ & $17(100)$ \\
\hline \multicolumn{4}{|l|}{ Training } \\
\hline Yes & $7(100)$ & $16(100)$ & $16(94.1)$ \\
\hline No & 0 & 0 & $1(5.9)$ \\
\hline \multicolumn{4}{|c|}{ Coverage of needs by income from the activity } \\
\hline No & 0 & 0 & 0 \\
\hline Good & $07(100)$ & $16(100)$ & $11(64.7)$ \\
\hline Very good & 0 & 0 & $6(35.3)$ \\
\hline Product & dibi Hausa & dibi Moorish & dibi Senegalese \\
\hline Sales unit & Portion & Weight $(\mathrm{kg})$ and portion & Weight $(\mathrm{kg})$ and portion \\
\hline Heat source & Coal & Wood & Wood \\
\hline
\end{tabular}

TAMB levels on the RSM from the Hausa dibiteries had significantly increased at 2 and 10 months after intervention trial $(P<0.05)$. In contrast, fecal coliform levels on the RSM from the Moorish dibiteries had significantly decreased at 2 and 10 months after intervention $(P<0.05)$. A significant increase in the mean $S$. aureus levels on the RSM from the
Hausa dibiteries was noted at 2 months post-intervention compared with 1 month pre-intervention and 10 months post-intervention $(P<0.05)$ (Table 5).

The RSM samples from dibiteries where only training was conducted and those from dibiteries receiving training, hygiene kits, and products were significantly more often 


\section{TABLE 4. Categorization of the level of satisfaction of the microbiological quality of}

roasted sheep meat before and after interventiona

\begin{tabular}{|c|c|c|c|c|}
\hline \multirow{2}{*}{ Step } & \multicolumn{3}{|c|}{ No. of samples } & \multirow{2}{*}{$\begin{array}{c}\% \\
\begin{array}{c}\text { satisfactory } \\
\text { samples }\end{array}\end{array}$} \\
\hline & Satisfactory & Unsatisfactory & Total analyzed & \\
\hline 1 mo pre-intervention & 28 & 12 & 40 & 70 \\
\hline 2 mo post-intervention & 30 & 10 & 40 & 75 \\
\hline 10 mo post-intervention & 29 & 6 & 35 & 83 \\
\hline
\end{tabular}

Statistical parameters: $\chi^{2}=1.689, \mathrm{dl}=2, P=0.43$

${ }^{a}$ Quality based on presence of TAMB, fecal coliforms, and S. aureus.

TABLE 5. Microbial load of roasted sheep meat according to the type of dibiterie before and after intervention

\begin{tabular}{|c|c|c|c|c|c|}
\hline \multirow{2}{*}{ Bacteria } & \multirow{2}{*}{$\begin{array}{l}\text { Type of } \\
\text { dibiterie }\end{array}$} & \multicolumn{3}{|c|}{ Mean \pm SD $(\log \mathrm{CFU} / \mathrm{g})^{a}$} & \multirow{2}{*}{$P$} \\
\hline & & 1 mo pre-intervention & 2 mo post-intervention & 10 mo post-intervention & \\
\hline \multirow{3}{*}{ TAMB } & Moorish & $4.85 \pm 1.11 \mathrm{~A}$ & $4.99 \pm 0.55 \mathrm{~A}$ & $4.38 \pm 1.36 \mathrm{~A}$ & 0.278 \\
\hline & Hausa & $5.11 \pm 0.64 \mathrm{~A}$ & $6.04 \pm 0.44 \mathrm{~B}$ & $6.18 \pm 0.69 \mathrm{~B}$ & 0.018 \\
\hline & Senegalese & $4.60 \pm 0.97 \mathrm{~A}$ & $4.59 \pm 0.93 \mathrm{~A}$ & $4.75 \pm 1.37 \mathrm{AB}$ & 0.138 \\
\hline \multirow{3}{*}{ Fecal coliforms } & Moorish & $2.47 \pm 1.78 \mathrm{C}$ & $1.58 \pm 1.09 \mathrm{CK}$ & $1.02 \pm 0.08 \mathrm{DK}$ & 0.009 \\
\hline & Hausa & $2.45 \pm 1.43 \mathrm{CD}$ & $3.87 \pm 1.54 \mathrm{D}$ & $2.77 \pm 1.94 \mathrm{CD}$ & 0.319 \\
\hline & Senegalese & $1.85 \pm 1.44 \mathrm{C}$ & $1.97 \pm 1.44 \mathrm{C}$ & $1.99 \pm 1.71 \mathrm{CD}$ & 0.959 \\
\hline \multirow{3}{*}{ Staphylococcus aureus } & Moorish & $2.34 \pm 0.90 \mathrm{E}$ & $2.00 \pm 0.00 \mathrm{E}$ & $2.00 \pm 0.00 \mathrm{E}$ & 0.138 \\
\hline & Hausa & $2.55 \pm 0.95 \mathrm{E}$ & $3.88 \pm 0.90 \mathrm{~F}$ & $2.00 \pm 0.00 \mathrm{E}$ & 0.004 \\
\hline & Senegalese & $2.12 \pm 0.48 \mathrm{E}$ & $2.26 \pm 0.68 \mathrm{E}$ & $2.18 \pm 0.66 \mathrm{E}$ & 0.823 \\
\hline
\end{tabular}

${ }^{a}$ Within each column and each bacterial group, means followed by different letters are significantly different $(P<0.05)$. Within each row, each bacterial group, and each type of dibiterie, means followed by different letters are significantly different $(P<0.05)$.

satisfactory in terms of levels of TAMB, coliforms, and $S$. aureus at 2 months but not at 10 months post-intervention compared with dibiteries that received no intervention and those that received only hygiene kits and products (Table 6). However, no significant difference regarding the level of satisfactory microbiological quality of the intervention groups was observed before and after the intervention (Table 6).

\section{Managerial performance of dibiteries and commercial and financial aspects pre- and post-intervention}

The income account analysis revealed that the gross margin (986.03 USD) and net profit (506.9 USD) per month of the dibiteries were lower after the intervention than before the intervention (990.3 and 525.5 USD, respectively); however, the difference was not significant $(P>0.05)$. The gross margin ratio (23\%) achieved by the dibiteries was positive and did not differ before and after the intervention. The results indicate that the operating income ratio of the dibiteries before intervention was slightly higher (13\%) than that after intervention (12\%) but that the rate of return (economic profitability) of the dibiteries before and after the intervention (14\%) did not differ $(P>0.05)$.

The level of production of dibiteries averaged $513 \mathrm{~kg}$ of mutton per month. The total cost of production of roasted mutton before the intervention (3,710.5 USD per month) was lower than that after intervention (3,729.1 USD per month), but this difference was not significant. The surplus or the margin that the improvement of the quality of RSM adds on the cost of producing a kilogram of RSM before the intervention was 0.04 USD. 


\begin{tabular}{|c|c|c|c|c|}
\hline \multirow[t]{2}{*}{ Group } & \multicolumn{3}{|c|}{$\%$ satisfactory samples ${ }^{a}$} & \multirow{2}{*}{$P$} \\
\hline & 1 mo pre-intervention & 2 mo post-intervention & 10 mo post-intervention & \\
\hline 1. Control & $78.57 \mathrm{~A}$ & $64.28 \mathrm{~A}$ & $84.62 \mathrm{~A}$ & 0.892 \\
\hline 2. Training & $83.33 \mathrm{AB}$ & $100.00 \mathrm{~B}$ & $60 \mathrm{AB}$ & 0.996 \\
\hline 3. Hygiene kits, products & $60.00 \mathrm{~A}$ & $50.00 \mathrm{~A}$ & $90 \mathrm{~A}$ & 0.648 \\
\hline 4. Training, hygiene kits, products & $60.00 \mathrm{AB}$ & $100.00 \mathrm{~B}$ & $85.71 \mathrm{AB}$ & 0.064 \\
\hline \multicolumn{5}{|l|}{ Statistical parameters } \\
\hline $\mathrm{dl}$ & 3 & 3 & 3 & \\
\hline$x^{2}$ & 1.95 & 9.52 & 2.267 & \\
\hline $\mathrm{P}$ & 0.58 & $<0.05$ & 0.519 & \\
\hline
\end{tabular}

${ }^{a}$ Within each column, means followed by different letters are significantly different $(P<0.05)$. Within each row, means followed by different letters are significantly different $(P<0.05)$.

\section{DISCUSSION}

According to the socio-demographic profile of the tenants of dibiteries and based on their production processes, three types of dibiteries were identified among the 40 dibiteries studied.

The same three types of dibiteries were identified previously in a study conducted the managerial performance of 163 dibiteries in Dakar and its suburbs (16). In the present study of 40 dibiteries assessed for contamination of RSM by TAMB, coliforms, and S. aureus, $70 \%$ of samples were satisfactory 1 month before the hygiene intervention, $75 \%$ were satisfactory 2 months after the intervention, and $83 \%$ were satisfactory 10 months after the intervention. Although the trend was toward better hygiene, statistical analyses revealed that the differences between sampling times were not significant. The significant increase in TAMB, coliform, and $S$. aureus levels in the RSM from the Hausa dibiteries compared with the Moorish and Senegalese dibiteries at 2 months post-intervention and in TAMB levels 10 months post-intervention indicates that the Hausa dibiteries did not change their hygiene practices for meat processing. The hygiene of the Hausa dibiteries did not improve after the intervention possibly because of the reluctance of tenants to follow advice on good hygiene and/ or because of particular Hausa practices used when preparing the food product. In those restaurants, the meat was processed and often kept throughout the entire day without any protection or refrigeration and was served cold to consumers. Condiments or raw ingredients (e.g., onion and kan-kan) can also be a source of contamination. In Hausa dibiteries, raw onion and chili was added to the RSM when served, whereas in Moorish dibiteries the onions were added to the meat during cooking.

Ingredients used at roasted meat kiosks often are contaminated with microorganisms. In Côte d'Ivoire, an analysis of the microbiological quality of 133 samples of kan-kan from 90 sellers of RSM revealed that $47 \%$ of the samples were contaminated with E. coli, $100 \%$ were contaminated with total coliforms, $90 \%$ were contaminated with sulfite-reducing anaerobes, and $96 \%$ were contaminated with fungi (19). The kan-kan also contained high concentrations of mycotoxins produced by fungi and linked to poor storage conditions, constituting a potential risk for consumers health (19).

The RSM samples from the dibiteries that received training only and from those that received training, hygiene kits, and products were significantly more often satisfactory in terms of TAMB, coliforms, and S. aureus 2 months post-intervention than were the RSM samples from dibiteries receiving no intervention and those receiving only hygiene kits and products. However, at 10 months postintervention, tenants were less likely to implement the good hygiene practices taught during the training. The incentives to apply the good hygiene practices may have decreased with the depletion of the products received by the dibiterie tenants during the intervention, who may have failed to replace these products.

In a previous study conducted in Dakar with the same 40 dibiteries in 2014, half of all RSM sold in those restaurants was assessed as unsatisfactory for fecal coliforms, E. coli, and mesophilic bacteria (20). Previously, $A_{w}$ (2) had found that only 5\% of RSM sold in dibiteries in Dakar was safe for consumption. Both studies on RSM revealed poor hygiene in Dakar dibiteries. This sanitation deficit is one of the causes of the deterioration of products, resulting in a loss of income for dibiterie tenants. The results of the present study revealed the effect of the intervention to improve quality; however, the one-off training had only short-term benefits, which faded without a refresher course. 
As part of the intervention, each of the 40 dibiteries received a hygiene kit worth 61.2 USD. Because of this material cost, the total cost of production for the dibiteries pre- and post-intervention did not differ. However, the gross margin ratio (23\%), which expresses the commercial efficiency of the company, and the rate of return (14\%), which explains the financial profitability before and after intervention, remained unchanged because there was no significant difference between the gross margins before and after the intervention. The positive gross margin ratio indicated the positive commercial performance of the assessed businesses, suggesting that the costs associated with the intervention did not change the sales of the RSM by these dibiteries. The operating income ratio before or after the intervention was $>5 \%$. The rate of return obtained in this study means that investing ( 0.16 USD) in roasted meat of dibiteries makes it possible to release 0.02 USD of net profit before and after the intervention. This rate is much higher than the borrowing rate practiced by the local banks, ( $12 \%$ to $15 \%$ for banks and; $17 \%$ to $22 \%$ for microfinance institutions in 2019), which indicates the profitability of the business. The cost of the intervention in the dibiteries did not have a negative impact on the commercial profitability, the operating profitability, or the economic profitability of these restaurants.

Two months after the intervention, the investment to improve the hygiene of the dibiteries and the quality of RSM was estimated at $0.04 \mathrm{USD} / \mathrm{kg}$. This cost had an effect on the hygiene of the dibiteries and the quality of RSM during the 2 months when the renewable products from the hygiene package were still being used. The dibiteries have a considerable margin on the selling price to invest in improving the hygiene and the quality of the finished products. The surplus of $0.04 \mathrm{USD} / \mathrm{kg}$ that this intervention added to the production cost of RSM would be totally absorbed by investing sustainably in hygiene and quality. This investment would increase the confidence and satisfaction of the customers and thus would increase the income or profitability of the dibiteries in the long term.

This study had some limitations. The intervention strategies were based on the sample of 40 dibiteries previously evaluated by Yougbaré (20), who had qualitatively characterized the risks of contamination of the roasted meat value chain from the slaughterhouse to the finished RSM. The insignificant decrease in hygiene indicators could be linked to the small number of dibiteries included in this study. Although the tenants in the four intervention groups had very similar characteristics (e.g., level of education, gender, marital status, experience, and family training), the intervention strategies did not take into account the technological specifications of roasted meat production from each type of dibiterie. The microbiological analyses were conducted on the combined roasted meat and ingredients to better evaluate the overall importance of the intervention strategy. Future research should be conducted with a larger number of dibiteries and separate analyses of roasted meat and ingredients.

Although no significant reduction in the contamination of RSM was found after the hygiene intervention, the RSM samples from dibiteries that received training only and those that received training, hygiene kits, and products were significantly more often satisfactory regarding their contamination by TAMB, coliforms, and $S$. aureus 2 months after the training but not 10 months after the training. The dissemination of training and hygiene packages was economically viable; however, to achieve long-term behavior change implementing the good hygiene practices learned in the training, periodic refresher training sessions may be needed.

\section{ACKNOWLED GMENTS}

We thank the International Livestock Research Institute, the CGIAR Research Program on Agriculture for Nutrition and Health, and the "Safe Food, Fair Food" project (funded by the Federal Ministry for Economic Cooperation and Development, Germany, grant 81141843). The authors acknowledge support from the DELTAS Africa Initiative (Afrique One-ASPIRE /DEL-15-008). Afrique OneASPIRE is funded by a consortium of donors including the African Academy of Sciences, 3 Acknowledgement Alliance for Accelerating Excellence in Science in Africa, the New Partnership for Africa's Development Planning and Coordinating Agency, the Wellcome Trust (107753/A/15/Z), and the government of the United Kingdom. We are grateful for the valuable contributions of Jasmina Saric (English language of the manuscript), Daouda Dao (methodology), Konan Yao (data analysis), Serge Niangoran Bakou (logistic), the senior technicians of the laboratory of EISMV, field workers, and translators. We also thank the tenants of dibiteries and all others who were willing to participate in this study.

\section{REFERENCES}

1. Association Française de Normalisation. 2004. Microbiologie des aliments: méthode de routine pour le dénombrement des staphylocoques à coagulase positive par comptage des colonies à $37^{\circ} \mathrm{C}$. Technique avec confirmation des colonies. NF V08-057-1. Association Française de Normalisation, Paris.

2. Aw, A. 1996. Contribution à l'étude de la qualité des viandes grillées préparées dans les dibiteries (grilladeries sénégalaises) dans la région de Dakar. Available at: http://www. beep.ird.fr/collect/eismv/index/assoc/ TD96-44.dir/TD96-44.pdf. Accessed 25 April 2019.

3. Bonfoh, B., C. Roth, A. N. Traoré, A. Fané, C. F. Simbé, I. O. Alfaroukh, J. Nicolet, Z. Farah, and J. Zinsstag. 2006. Effect of washing and disinfecting containers on the microbiological quality of fresh milk sold in Bamako (Mali). Food Control 17:153-161.

4. Dione, M. M., M. Leven, B. Garin, T. Marcotty, and S. Geerts. 2009. Prevalence and antimicrobial resistance of Salmonella isolated from broiler farms, chicken carcasses, and street-vended restaurants in Casamance, Senegal. J. Food Prot. 72:2423-2427. 
5. Dosso, M., M. Coulibaly, and A. Kadio. 1998 Place des diarrhées bactériennes dans les pays en développement. Bull. Soc. Pathol. Exot. 5:402-405.

6. European Commission. 2007. Commission Regulation (EC) No 1441/2007 of 5 December 2007 amending Regulation (EC) No $2073 / 2005$ on microbiological criteria for foodstuffs. Off. J. Eur. Union L 322:12-29.

7. Food and Agriculture Organization of the United Nations. 2018. World food and agriculture. Statistical pocketbook. Available at: http://www.fao.org/3/CA1796EN/ ca1796en.pdf. Accessed 25 April 2019.

8. International Organization for Standardization. 2013. Microbiology of the food chain-horizontal method for the enumeration of microorganisms. NF EN ISO 4833. International Organization for Standardization, Geneva.

9. International Organization for Standardization. 2006. Microbiology of food and animal feeding stuffs - horizontal method for the enumeration of coliforms. ISO 4832. International Organization for Standardization, Geneva.

10. International Organization for Standardization. 1999. Microbiology of food and animal feeding stuffs - horizontal method for the enumeration of coagulase-positive staphylococci (Staphylococcus aureus and other species). NF EN ISO 6888. International Organization for Standardization, Geneva.
11. Keiser, A. M. 2004. Gestion financière, 7th ed. ESKA, Paris.

12. Marascuilo, L. A., and R. C. Serlin. 1988 Statistical methods for the social and behavioral sciences. W. H. Freeman, New York.

13. Ministère de l'agriculture et de la pêche. 2001. Critères microbiologiques applicables aux aliments. DGAL/SDHA N2001-8090, 27 June 2001. Direction générale de l'alimentation, Ministere de l'agriculture et de la peche, Paris.

14. Ministère de l'élevage et des productions animales, Sénégal. 2018. Rapport de revue annuelle du secteur de l'élevage. Available at: http://www.elevage.gouv.sn/ sites/default/ files/Revue\%20annuelle\%202018.pdf. Accessed 22 April 2019.

15. Nabarro, D., and C. Wannous. 2014. The potential contribution of livestock to food and nutrition security: the application of the One Health approach in livestock policy and practice. Rev. Sci. Tech. Off. Int. Epiz. 33:475-485.

16. Orou Seko, M., W. Ossebi, G. S. Traoré, A. P. N. Ndour, J. Saric, G. Fokou, D. Dao, and B. Bonfoh. 2019. Typology, technical efficiency and scale economy of dibiteries in Dakar, Senegal. AAS Open Res. 2. https://doi. org/10.12688/aasopenres.12953.2
17. Stevens, A., Y. Kaboré, J.-D. Perrier-GrosClaude, Y. Millemann, A. Brisabois, M. Catteau, J.-F. Cavin, and B. Dufour. 2006. Prevalence and antibiotic-resistance of Salmonella isolated from beef sampled from the slaughterhouse and from retailers in Dakar (Senegal). Int. J. Food. Microbiol. 15:178-186.

18. World Health Organization. 2016. WHO estimates of the global burden of foodborne diseases: foodborne disease burden epidemiology reference group 2007-2015. World Health Organization, Geneva.

19. Yapo, A. 21 December 2019. Presentation colloque [E-mail:yarmelelyse@gmail.com]. Available from the author at orousekom@ gmail.com.

20. Yougbaré, B. 2014. Appréciation des risques de contamination microbienne de la viande de petits ruminants dans les abattoirs et les dibiteries de Dakar, Sénégal. Available at: https://cgspace.cgiar.org/bitstream/ handle/10568/41906/YougbareMVPH\%20 thesis.pdf ? sequence $=1$ \&isAllowed $=y$. Accessed 24 March 2019. 